(c) American Dairy Science Association, 2005.

\title{
Effects of Photoperiod During the Dry Period on Prolactin, Prolactin Receptor, and Milk Production of Dairy Cows
}

\author{
T. L. Auchtung, ${ }^{1}$ A. G. Rius, ${ }^{1}$ P. E. Kendall, ${ }^{1}$ T. B. McFadden, ${ }^{2}$ and G. E. Dahl ${ }^{1}$ \\ ${ }^{1}$ Department of Animal Sciences, University of Illinois, Urbana 61801 \\ ${ }^{2}$ Department of Animal Sciences, University of Vermont, Burlington 05405
}

\begin{abstract}
Cows exposed to short day photoperiod during the dry period produce significantly more milk in their subsequent lactation than cows exposed to long days. The mechanism(s) underlying this effect are unknown. Because concentrations of prolactin (PRL) in circulation are consistently affected by changes in photoperiod, we hypothesized that alterations in the prolactin axis and sensitivity of the mammary gland to prolactin signaling may mediate photoperiodic effects in dry cows. The objective of this study was to determine the effects of exposure to different lengths of daylight during the dry period on circulating PRL and PRL receptor (PRL-R) mRNA expression in lymphocytes and mammary tissue during the transition to lactation. Multiparous Holstein cows were dried off $62 \mathrm{~d}$ before calving and assigned to long day ( $16 \mathrm{~h}$ light: $8 \mathrm{~h}$ dark) or short day photoperiod (8 h light: $16 \mathrm{~h}$ dark). During the dry period, PRL and PRL-R mRNA were analyzed biweekly in plasma and lymphocytes, respectively. Expression of PRL-R mRNA was assessed in mammary biopsies during the dry and periparturient periods. Dry matter intake (DMI) was recorded through $21 \mathrm{~d}$ of lactation, and milk yield was recorded until $120 \mathrm{~d}$ in milk. Short day photoperiod was associated with reduced PRL, whereas milk yield and expression of PRL-R mRNA in lymphocytes and mammary tissue were increased. Cows on short days had higher DMI during the dry period but did not differ in DMI after parturition. These data support the concept that greater responsiveness and sensitivity to PRL during transition to lactation may be associated with an increase in subsequent milk yield.
\end{abstract}

(Key words: photoperiod, dry period, prolactin receptor, dairy cow)

Abbreviation key: LDPP = long day photoperiod, $\mathbf{P R L}=$ prolactin, $\mathbf{P R L}-\mathbf{R}=$ prolactin receptor, $\mathbf{S D P P}=$ short day photoperiod.

Received March 25, 2004.

Accepted August 18, 2004

Corresponding author: Geoffrey E. Dahl; e-mail: gdahl@uiuc.edu.

\section{INTRODUCTION}

Photoperiod management has a number of physiological effects on the dairy cow. During lactation, greater duration of exposure to light (i.e., long days) relative to controls results in increases in milk production during lactation (Dahl et al., 2000). Conversely, cows exposed to a reduced duration of light during the dry period produced more milk during the subsequent lactation, relative to cows exposed to longer days (Miller et al., 2000). In lactating cows there is evidence that increased circulating insulin-like growth factor-I is a mediator of the galactopoietic effect of long day photoperiod (LDPP; Dahl et al., 1997), particularly as other galactopoietic hormones, such as growth hormone and thyroid hormone, do not appear to be affected by photoperiod management. However, the endocrine mechanism underlying the effect of photoperiod on health and performance of dry cows remains unknown. The consistent changes in prolactin (PRL) concentrations observed during photoperiod manipulation (Dahl et al., 2000) make it a potential candidate. Of particular importance is the possibility that an animal's ability to respond to available circulating PRL, referred to as PRL sensitivity, may be dictated by relative levels of PRL-receptor (PRL-R) expression in target cells.

Several lines of evidence support the concept that alterations in PRL sensitivity may underlie the effects of short day photoperiod (SDPP) in dry cows. First, PRL is critically important to the secondary stage of lactogenesis that occurs at parturition (Akers, 1985). In addition, PRL-R expression fluctuates during physiological changes, such as the transition from pregnancy to lactation (Jahn et al., 1991; Feng et al., 1998). Finally, we have reported an inverse relationship between circulating PRL and expression of PRL-R mRNA in mammary parenchymal tissue of steers exposed to different photoperiods (Auchtung et al., 2003a). However, the influence of photoperiod on PRL-R expression in the mammary gland of mature cows has not been characterized.

Another line of evidence relates to the observation that many mammalian species express PRL-R in various tissues, including immune-related tissues (Toura- 
Table 1. Ingredient composition of the diet fed to experimental cows exposed to a long-day photoperiod (LDPP; $\mathrm{n}=20$ ) or a short day photoperiod (SDPP; $\mathrm{n}=19$ ) during the dry period.

\begin{tabular}{|c|c|c|}
\hline Ingredient & $\begin{array}{l}60 \text { to } 22 \mathrm{~d} \\
\text { prepartum }\end{array}$ & $\begin{array}{l}21 \text { to } 0 \mathrm{~d} \\
\text { prepartum }\end{array}$ \\
\hline & $\longrightarrow$ & \\
\hline Wheat straw & 26.15 & \\
\hline Alfalfa silage & 41.68 & 25.14 \\
\hline Corn silage & 21.10 & 24.49 \\
\hline Alfalfa hay & $\ldots$ & 13.40 \\
\hline Cottonseed & & 4.18 \\
\hline Concentrate $590^{1}$ & 11.07 & \\
\hline Concentrate $592^{2}$ & & 32.79 \\
\hline Crude protein & 14.60 & 15.20 \\
\hline $\mathrm{NE}_{\mathrm{L}}(\mathrm{Mcal} / \mathrm{kg})$ & 0.31 & 0.34 \\
\hline
\end{tabular}

${ }^{1}$ Formulation includes $65.08 \%$ ground shelled corn, $27.66 \%$ soybean meal, $2.39 \%$ UIUC Dairy $8011,2.09 \% \mathrm{NaCl}, 1.59 \%$ vitamin E, $0.79 \%$ $\mathrm{Ca}_{2} \mathrm{P}_{2} \mathrm{O}_{7}$, and $0.40 \%$ vitamin $\mathrm{A}$ and $\mathrm{D}$, on a $\mathrm{DM}$ basis.

${ }^{2}$ Formulation includes $49.80 \%$ ground shelled corn, $5.04 \%$ Soy Plus, $29.53 \%$ soy hulls, $0.82 \%$ UIUC Dairy $8011,0.56 \% \mathrm{NaCl}, 0.56 \%$ $\mathrm{Ca}_{2} \mathrm{P}_{2} \mathrm{O}_{7}, 3.87 \%$ limestone, $5.52 \% \mathrm{MgSO}_{4}, 3.31 \% \mathrm{CaCl}_{2}, 0.82 \%$ vitamin $\mathrm{E}$, and $0.16 \%$ vitamin $\mathrm{A}$ and $\mathrm{D}$, on a DM basis.

ine et al., 1994; Schuler et al., 1997). Indeed, our laboratory demonstrated an inverse relationship between PRL concentration and PRL-R mRNA expression in lymphocytes when steers were exposed to different photoperiods (Auchtung et al., 2003a). Changes in mammary tissue observed with alterations in photoperiod exposure may be mediated through a mechanism associated with the PRL axis. Based on these lines of evidence, the objective of the present study was to characterize photoperiodic effects on circulating PRL and PRL-R mRNA expression in mammary tissue and lymphocytes during the dry period as an index of PRL sensitivity during the transition to lactation. In addition, we sought to confirm the effects of photoperiod during the dry period on DM intake and subsequent milk production and composition.

\section{MATERIALS AND METHODS}

\section{General}

All procedures and photoperiod manipulations were approved by the UIUC Institutional Animal Care and Use Committee. Forty multiparous Holstein cows were dried off according to standard University of Illinois protocol. The protocol consisted of infusion of all 4 quarters of the mammary gland with cephapirin benzathine (Cefa-dri, Fort Dodge, IA) and an initial vaccination (first of 3 total; dry-off, 30-d dry, and within $48 \mathrm{~h}$ postpartum) against gram-negative core antigens (Escherichia coli J5; Upjohn J-5 Bacterin, Pfizer, Kalamazoo, MI). Using a Calan feeding system, cows were fed individually, ad libitum. Intake and refusals were recorded daily. Composition of the diet during the dry period is described in Table 1. Dry matter intake was monitored during the dry period and through $21 \mathrm{~d}$ postcalving. Cows were milked twice daily throughout their lactation. Milk samples were sent weekly, for the first 16 wk of lactation, to Dairy Laboratory Services, Inc., (Dubuque, IA) for standard composition analysis. Daily milk yields were averaged to calculate weekly values.

Cows were randomly assigned to 1 of 2 photoperiod exposures: LDPP (16 h light: 8 h dark; $n=20$ ) or SDPP (8 h light: $16 \mathrm{~h}$ dark; $\mathrm{n}=19$ ), balanced for calving date and milk production in the previous lactation. Photoperiod exposure began at dryoff, which averaged of $62 \pm$ $3 \mathrm{~d}$ before calving. Following parturition, cows were returned to the herd and natural photoperiod from April (sunrise $0600 \mathrm{~h}$ : sunset $2000 \mathrm{~h}$ ) through June 2002 (sunrise 0500 h: sunset 2100 h). During the dry period, cows were housed in an enclosed, ventilated maternity barn with controlled light exposure. Lights were on at 0800 and off at 1600 or $2400 \mathrm{~h}$ for SDPP and LDPP, respectively.

\section{Blood Collection and Prolactin Assays}

Blood samples $(10 \mathrm{~mL})$ were collected from each cow between 0830 and $1030 \mathrm{~h}$ via jugular venipuncture twice weekly starting at dryoff and continuing until calving. Blood samples were collected into a sterile evacuated tube containing sodium heparin (Vacutainer, Becton Dickinson and Co., Franklin Lakes, NJ) and placed immediately on ice. Plasma was harvested by centrifugation at $1850 \times g$ for 20 min at $4^{\circ} \mathrm{C}$ within $2 \mathrm{~h}$ of blood collection. Plasma was stored at $-20^{\circ} \mathrm{C}$ until PRL radioimmunoassay as described by Miller et al. (1999). Mean intra- and interassay coefficients of variation (2 assays) were 7.6 and $12.8 \%$, respectively. Assay sensitivity averaged $0.97 \mathrm{ng} / \mathrm{mL}$.

\section{Lymphocyte Isolation}

Bovine peripheral blood mononuclear cells were used as the source of lymphocyte mRNA for real-time PCR. Bovine mononuclear cells were isolated from blood samples collected on sodium heparin by density gradient centrifugation through Histopaque-1077 (density: 1.077; Sigma Chemical Co., St. Louis, MO). Lymphocytes were washed only once in RPMI medium before RNA isolation to minimize RNA degradation.

\section{Mammary Biopsies}

Mammary biopsies were collected from a randomly selected subset of cows $(\mathrm{n}=12 ; 6$ per photoperiod assignment) on $d-45,-23,-9$, and +11 relative to calving, according to the method of Farr et al. (1996). Before biopsy, cows were sedated with Rompun (xylazine hy- 
drochloride; 35 to $45 \mu \mathrm{g} / \mathrm{kg}$ of BW) administered i.v. A $10-\mathrm{cm}^{2}$ area of skin on the selected quarter (approximately the midpoint of the gland to be biopsied) was clipped, then washed and rinsed with $70 \%$ ethanol and an iodine surgical scrub. The biopsy site was anesthetized by s.c. injection of $3 \mathrm{~mL}$ of lidocaine in a line block. A 2- to $4-\mathrm{cm}$ incision was made through the skin and underlying connective tissue capsule, avoiding any large subcutaneous blood vessels. A core $(70 \times 4 \mathrm{~mm}$ diameter) of mammary tissue was cut using the biopsy instrument (Farr et al., 1996), rotated by a slow-speed portable hand drill. After penetration of the tissue, the retractable blade was extended and rotated to sever the end of the tissue core. The sample was withdrawn with the blade extended. A plug of Surgicel absorbable hemostat $(3 \times 5 \mathrm{~cm})$ was then inserted into the wound. The skin incision was closed with Michel surgical clips (14 $\times 3 \mathrm{~mm}$ ). The tissue core was rapidly separated into fractions that were frozen on dry ice.

\section{Real-Time PCR}

Real-time PCR was performed as described in Auchtung et al. (2003a). Briefly, total RNA was extracted from mammary tissue and lymphocytes using Trizol reagent (Gibco BRL, Grand Island, NY) and stored at $-80^{\circ} \mathrm{C}$ until further processing. Complementary DNA prepared by reverse transcription primed by random hexamers (Strategene, La Jolla, CA) for use in realtime PCR. Taqman (Applied Biosystems, Foster City, CA) probes and primers were designed using Primer Express software for the long and short forms of PRL-R, and 18S rRNA was amplified for use as a normalization control. Detection was performed using an ABI PRISM 7700 Sequence Detector (Applied Biosystems). Using a standard curve, calculated input amounts were normalized to $18 \mathrm{~S}$ values. Final values are reported as expression values relative to control cDNA (mammary tissue collected before photoperiod exposure) or as a percentage of baseline within photoperiod (pre-exposure lymphocyte expression).

\section{Statistical Analyses}

Statistical analyses were performed using the SAS System v. 8.2 (SAS Institute, Inc., Cary, NC). A mixed model was used to analyze all data as repeated measures, using an unstructured covariance structure. Animals were blocked by previous milk production and specific comparisons were made for milk production, DMI, PRL concentrations, and PRL-R mRNA expression between LDPP and SDPP animals and across time. Daily ambient temperature and pre-exposure hormone values were used as covariates in the model analyzing

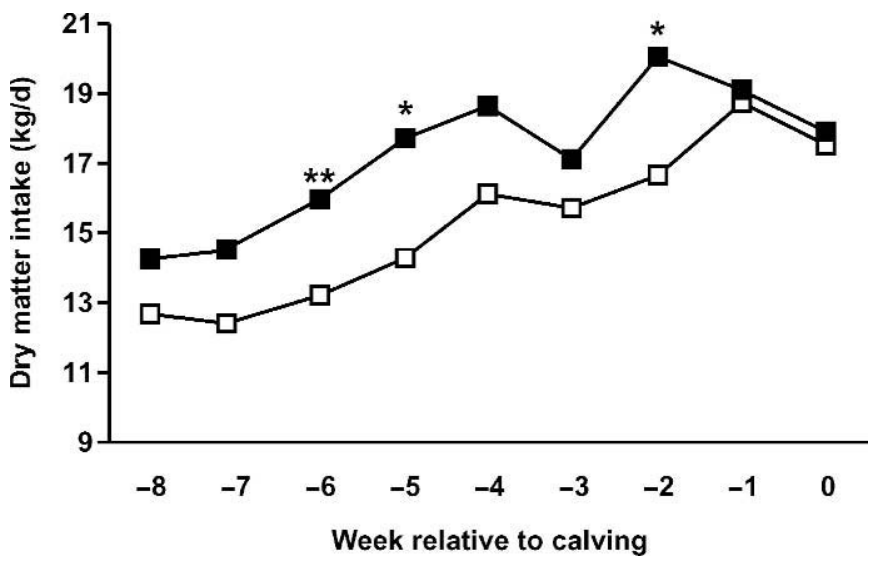

Figure 1. Dry matter intake during the dry period in cows on different photoperiods when dry. Solid squares (ם) represent short day photoperiod (SDPP; $\mathrm{n}=19$ ) and open squares $(\square)$ represent long day photoperiod (LDPP; $\mathrm{n}=20)$. Standard error of the difference $=$ $4.2 \mathrm{~kg} / \mathrm{d} . * P<0.05 ; * * P<0.01$.

PRL concentrations. Least square means and standard error of the difference are reported.

\section{RESULTS}

\section{Intake and Milk Production}

Dry matter intake of the cows during the dry period is depicted in Figure 1. Overall, feed intake was not statistically different $(P>0.10)$ but DMI was numerically greater in cows exposed to SDPP during the dry period than those on LDPP, with significant increases in DMI during wk $-6,-5$, and -2 relative to calving. Dry matter intake during the first $21 \mathrm{~d}$ of lactation did

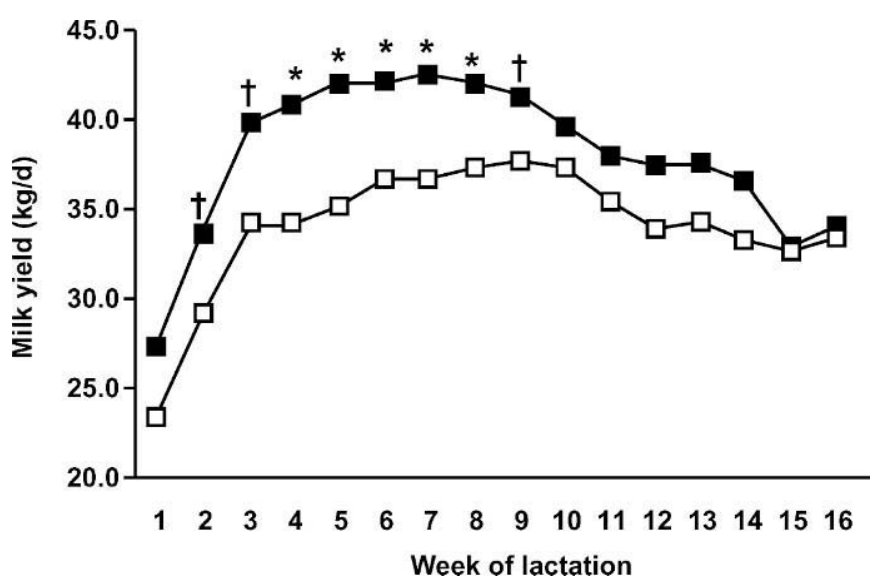

Figure 2. Average daily milk production during the first $16 \mathrm{wk}$ of lactation of cows exposed to different photoperiods during the dry period. Solid squares $(\square)$ represent short day photoperiod (SDPP; $\mathrm{n}=$ 18) and open squares $(\square)$ represent long day photoperiod (LDPP; $\mathrm{n}=$ 18). Standard error of the difference $=3.1 \mathrm{~kg} / \mathrm{d}$. ${ }^{*} P<0.05 ; \dagger P<0.10$. 
Table 2. Milk composition and dry matter intake during the first 16 wk of lactation of cows maintained on long (LDPP; $n=20$ ) or short day (SDPP; $n=19$ ) photoperiod exposure during the dry period.

\begin{tabular}{lrrr}
\hline Variable & LDPP & SDPP & SED \\
\hline Fat, \% & 4.00 & 3.80 & 0.25 \\
Protein, \% & 3.20 & 3.02 & 0.11 \\
Lactose, \% & 4.71 & 4.62 & 0.09 \\
Other solids, \% & 5.63 & 5.52 & 0.08 \\
Total solids, \% & 12.82 & 12.34 & 0.24 \\
MUN, mg/dL & $14.41^{\mathrm{a}}$ & $17.00^{\mathrm{b}}$ & 1.07 \\
\hline
\end{tabular}

${ }^{\mathrm{a}, \mathrm{b}}$ Within a row, values with different superscripts are different at $P<0.05$.

not differ between groups (14.41 vs. $14.62 \mathrm{~kg} / \mathrm{d} \pm 1.3$ for LDPP and SDPP cows, respectively).

During the first $16 \mathrm{wk}$ of lactation, cows exposed to SDPP during the dry period produced more milk $(P<$ 0.10 ) compared with those on LDPP (Figure 2). Data was lost from one cow in the SDPP group due to death during the dry period. Percentages of fat, protein, lactose, and solids in milk did not differ between groups $(P>0.10$; Table 2). However, during the first $8 \mathrm{wk}$ of lactation, MUN was significantly greater $(P<0.05)$ in cows exposed to SDPP during the dry period compared with LDPP cows (Table 2).

\section{Prolactin and Prolactin Receptor}

Concentrations of PRL in plasma did not differ between groups at dryoff but were significantly lower $(P$ $<0.05$ ) at 35 and $63 \mathrm{~d}$ after dryoff in cows exposed to SDPP when dry compared with those on LDPP (Figure 3 ). By 2 DIM, PRL concentrations were no longer different between groups.

Expression of long and short form PRL-R mRNA in lymphocytes is presented in Figures 4 and 5, respectively. Both long- (Figure 4) and short form (Figure 5) PRL-R expression in cows exposed to SDPP increased during the dry period, relative to pre-exposure levels. Cows treated with LDPP when dry showed decreased PRL-R expression relative to pre-exposure levels. Between photoperiod groups, cows exposed to SDPP had greater expression of both forms of PRL-R $(P<0.05)$, compared with LDPP cows. This difference persisted through the first few days of lactation.

Patterns of PRL-R mRNA expression in mammary tissue were similar to those of lymphocytes with regard to photoperiod exposure (Figures 6 and 7). Cows exposed to SDPP during the dry period had significantly greater PRL-R expression $(P<0.05)$ than cows exposed to LDPP when dry. This difference was observed regardless of the receptor form and persisted throughout the dry period and during the first days of lactation. There was an overall increase in long form PRL-R

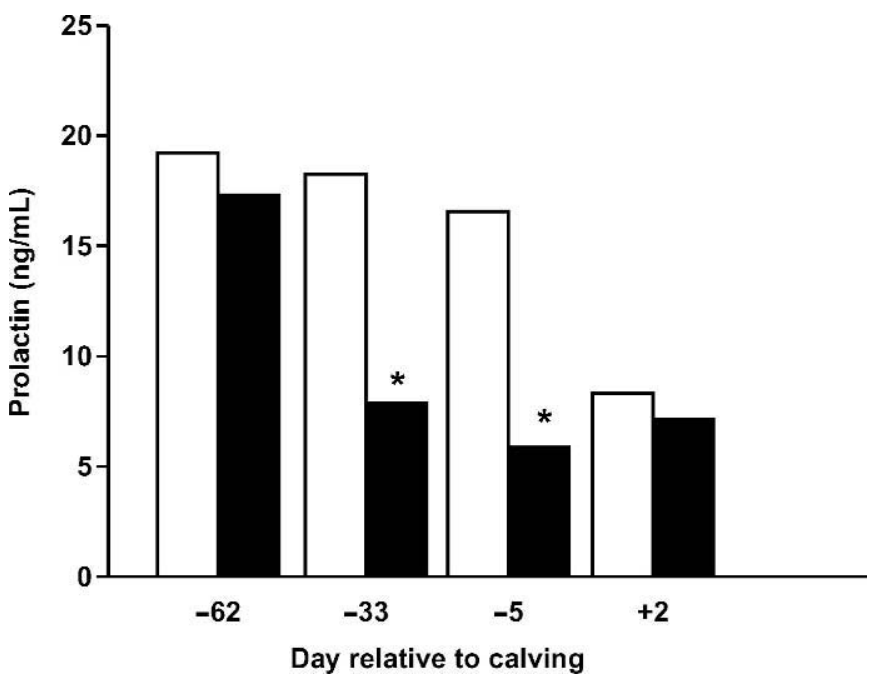

Figure 3. Concentrations of prolactin during the dry period of cows on different photoperiods throughout the dry period. Solid bars (ם) represent short day photoperiod (SDPP; $\mathrm{n}=19$ ) and open bars $(\square)$ represent long day photoperiod (LDPP; $\mathrm{n}=20$ ). Standard error of the difference $=5.2 \mathrm{ng} / \mathrm{mL}$. $* P<0.05$.

mRNA expression as the dry period progressed, particularly in the SDPP cows, whereas there was an overall decrease in short form PRL-R mRNA expression with the approach of parturition.

\section{DISCUSSION}

The results of the present study confirm that exposure of cows to SDPP during the dry period increases

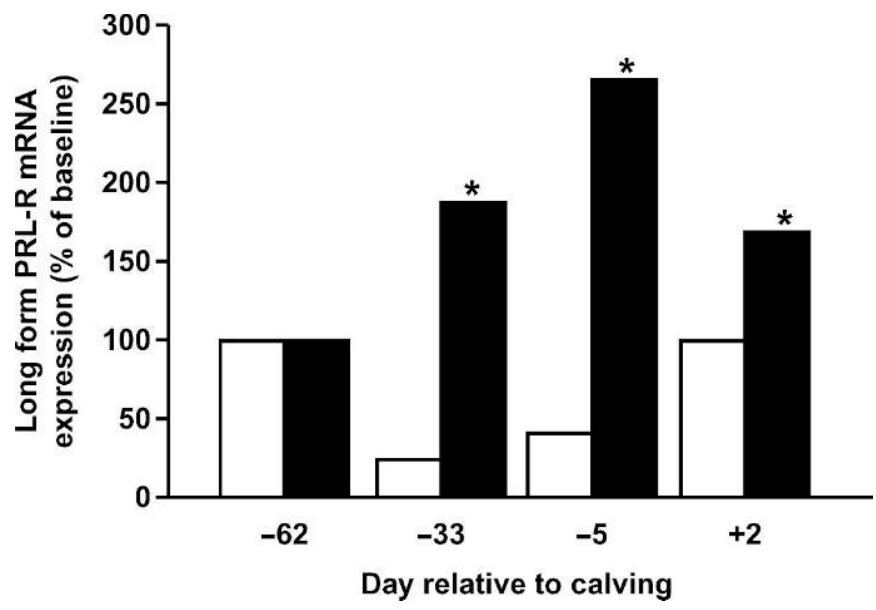

Figure 4. Effect of photoperiod management during the dry period on the long form of bovine prolactin receptor (PRL-R) mRNA expression in lymphocytes. Expression of PRL-R mRNA estimated by realtime PCR. Solid bars ( $)$ represent short day photoperiod (SDPP; $\mathrm{n}=19$ ) and open bars $(\square)$ represent long day photoperiod (LDPP; $\mathrm{n}=20$ ). Values are mRNA expression relative to baseline values $(*=$ $P<0.05)$. Standard error of the difference $=23.5 \%$. 


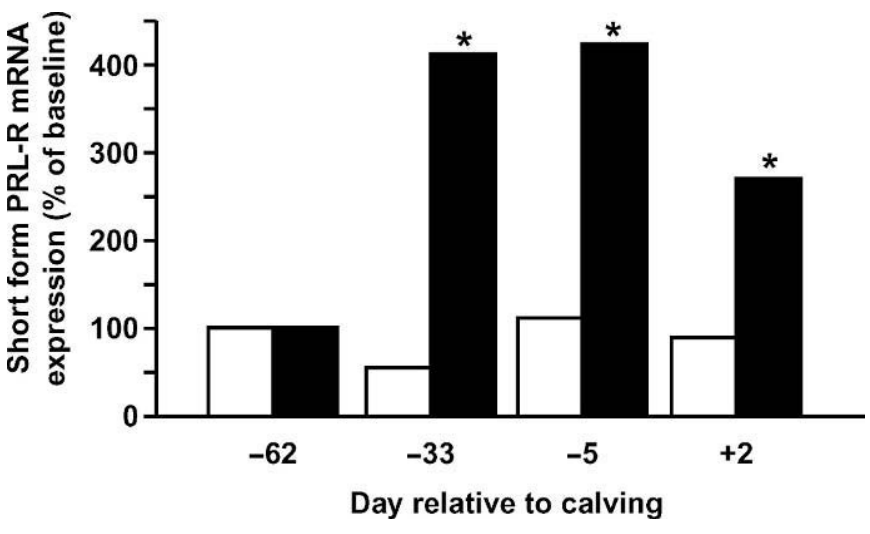

Figure 5. Effect of photoperiod management during the dry period on the short form of bovine prolactin receptor (PRL-R) mRNA expression in lymphocytes. Expression of PRL-R mRNA estimated by realtime PCR. Solid bars ( $\square$ ) represent short day photoperiod (SDPP; $\mathrm{n}=19$ ) and open bars $(\square)$ represent long day photoperiod (LDPP; $\mathrm{n}=20)$. Values are mRNA expression relative to baseline values $\left(^{*}=\right.$ $P<0.05)$. Standard error of the difference $=72.3 \%$.

milk production relative to animals exposed to LDPP (Miller et al., 2000; Dahl and Petitclerc, 2003). In general, milk composition was unchanged by photoperiod exposure, similar to our previous report (Miller et al., 2000). In addition, PRL concentrations in plasma were greater in LDPP cows relative to SDPP cows, similar to previous studies in dry cows (Miller et al., 2000) and pregnant heifers (Newbold et al., 1991). We have extended those reports with the observation that cows

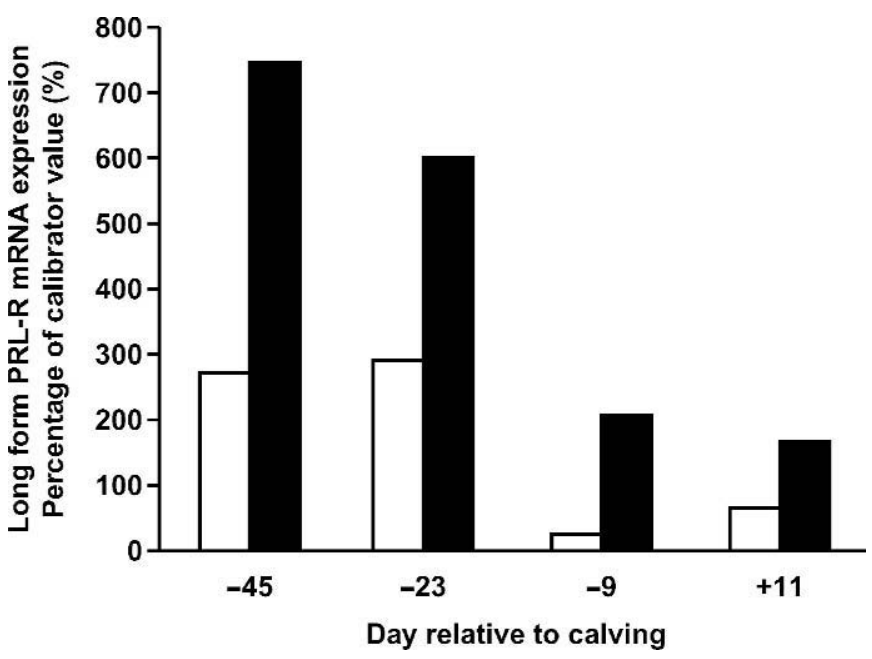

Figure 6. Effect of photoperiod management during the dry period on the long form of bovine prolactin receptor (PRL-R) mRNA expression in mammary tissue. Expression of PRL-R mRNA estimated by real-time PCR. Solid bars ( $\mathbf{\square})$ represent short day photoperiod (SDPP; $\mathrm{n}=6$ ) and open bars $(\square)$ represent long day photoperiod (LDPP; $\mathrm{n}=$ $6)$. Values are mRNA expression relative to calibrator values $(*=P$ $<0.05)$. Standard error of the difference $=258.2 \%$.

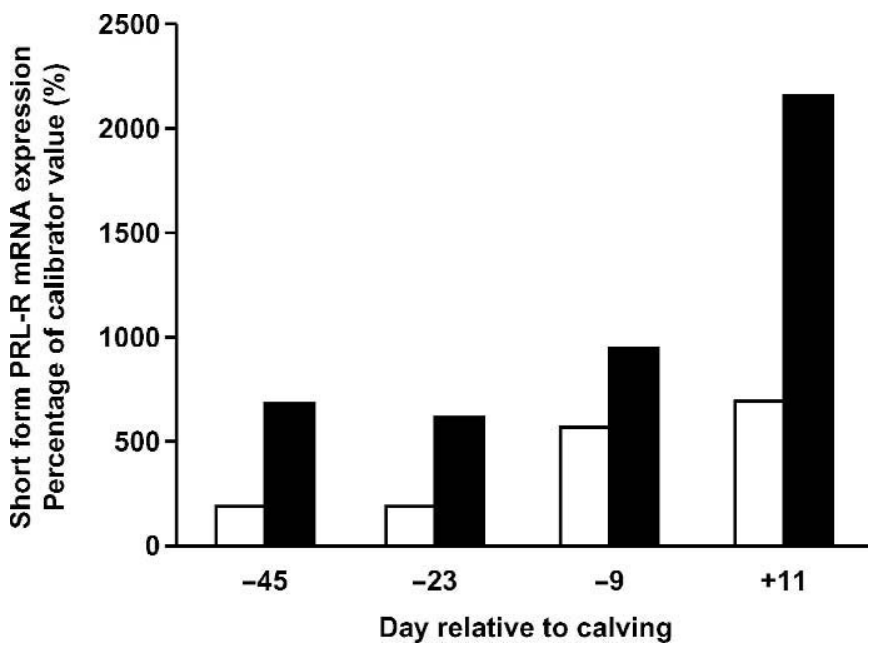

Figure 7. Effect of photoperiod management during the dry period on the short form of bovine prolactin receptor (PRL-R) mRNA expression in mammary tissue. Expression of PRL-R mRNA estimated by real-time PCR. Solid bars ( $\mathbf{\square})$ represent short day photoperiod (SDPP; $\mathrm{n}=6$ ) and open bars $(\square)$ represent long day photoperiod (LDPP; $\mathrm{n}=$ 6 ). Values are mRNA expression relative to calibrator values $\left(^{*}=P\right.$ $<0.05$ ). Standard error of the difference $=171.6 \%$.

exposed to SDPP during the dry period have greater expression of PRL-R mRNA in lymphocytes and mammary tissue, relative to LDPP cows. This increase was observed in both long and short forms of the PRL-R mRNA. The inverse relationship in this study between PRL and PRL-R has been observed previously (Djiane et al., 1983; Di Carlo et al., 1995). The sensitivity of an animal to PRL via this inverse relationship may be one mechanism whereby SDPP is affecting changes in the mammary gland.

Prolactin is necessary for complete differentiation of the bovine mammary secretory epithelial cells at the time of parturition (Akers et al., 1981a,b). Inhibition of the periparturient surge of PRL by treatment with bromocriptine (CB154) resulted in a higher percentage of undifferentiated mammary epithelial cells compared with untreated controls (Akers et al., 1981b). Prolactin receptor is important in mammary function of many species, such as the mouse. This can be observed in the prevention of successful lactation in most studies conducted with the PRL-R knockout mouse model (Ormandy et al., 2003). Because PRL and PRL-R influence commitment of mammary cells to produce milk components, it is possible that shifts in PRL sensitivity alter the extent of cellular differentiation during the postpartum period.

Bovine tissues express at least 2 forms of PRL-R: long and short forms. The long and short forms are highly conserved, with the short form having a truncated cytoplasmic domain (Schuler et al., 1997). Al- 
though the structure is conserved across many species, little is known about the importance of expression of the short form of PRL-R in bovine lymphocytes or mammary tissue. In the present study, long form PRL-R mRNA expression in bovine mammary tissue increased throughout the dry period. This is consistent with data from Smith et al. (1993) and Kazmer et al. (1986), which showed increases in PRL binding in the mammary gland as parturition approached. Those studies also noted that expression of lactogenic hormones, such as PRL, is down-regulated by pregnancy in bovine mammary tissue, resulting in an inverse relationship between PRL and PRL-R in the mammary gland.

Expression of short form PRL-R mRNA in this study followed the long form of PRL-R in lymphocytes during the dry period. However, expression of short form PRL$\mathrm{R}$ in mammary tissue was inversely related to the long form of PRL-R. The increased presence of the short form PRL-R mRNA around the initiation of the dry period, in conjunction with the decreased expression of the long form of PRL-R, could limit the ability of the long form to homodimerize, instead allowing for increased heterodimerization. Heterodimerization results in a substantial decrease in ligand binding and subsequent signaling (Berlanga et al., 1997; Jabbour and Kelly, 1997). The short form of PRL-R may act as a negative regulator by competing for PRL in the system but it also appears to be functionally active as it is able to overcome the deficiency of the long form of the receptor in PRL-R knockout mice such that mammary function is essentially restored in those animals (Binart et al., 2003). The increase in long form PRL-R mRNA expression as the dry period progresses, along with the decrease in expression of the short form PRL-R, particularly around parturition, may result in a greater response in mammary function.

The up-regulation of long form PRL-R mRNA expression in lymphocytes of SDPP cows compared with LDPP cows may be indicative of a benefit to the maternal immune system. Feng et al. (1998) observed an increase in PRL-R expression in immune tissues of the rat as they progressed into lactation. Recently, we have observed an increase in cellular immune function and general animal health in cows exposed to SDPP during the dry period relative to LDPP cows (Auchtung et al., 2004), during the same time that the PRL-R was upregulated in this study. In addition, we observed a decrease in somatic cell count and incidence of intramammary infections in cows exposed to SDPP during the dry period relative to LDPP cows (Auchtung et al., $2003 b)$. This improvement in mammary health persisted through the first 16 wk of lactation.

The parallel changes in PRL-R mRNA in lymphocytes and mammary tissue during the dry period and lacta- tion provide further evidence that lymphocyte PRL-R mRNA expression could be used to monitor PRL-R mRNA expression shifts in other tissues in a less invasive manner. Although comparisons between lymphocytes and mammary tissues are limited because the sampling times differed, and the pattern of expression differed between tissues, the general effect of photoperiod on PRL-R and circulating PRL was consistent with greater sensitivity in SDPP cows relative to those on LDPP.

\section{CONCLUSION}

Short day photoperiod exposure during the dry period increased milk production in the subsequent lactation compared with long day photoperiod exposure. Expression of prolactin receptor in lymphocytes and mammary tissue was inversely related to prolactin concentrations in cows exposed to different photoperiods during the dry period. Sensitivity to prolactin, particularly during the transition into lactation, may be associated with an increase in milk yield observed subsequent to photoperiod exposure.

\section{ACKNOWLEDGMENTS}

The authors wish to thank Ryan Graves, Brent Pollard, and Jennifer Dauderman for their assistance in animal handling and blood collection. Thanks to Emma Wall for assistance with processing of mammary tissue. A. F. Parlow provided prolactin hormone and antisera for radioimmunoassays. This research was funded by grants to G. E. Dahl from the State of Illinois through the Illinois Council on Food and Agricultural Research (Award \#02I-078-3) and US-Israel Binational Agricultural Research and Development Fund (Award \#US3201-01).

\section{REFERENCES}

Akers, R. M. 1985. Lactogenic hormones: Binding sites, mammary growth, secretory cell differentiation, and milk biosynthesis in ruminants. J. Dairy Sci. 68:501-519.

Akers, R. M., D. E. Bauman, A. V. Capuco, G. T. Goodman, and H. A. Tucker. 1981a. Prolactin regulation of milk secretion and biochemical differentiation of mammary epithelial cells in periparturient cows. Endocrinology 109:23-30.

Akers, R. M., D. E. Bauman, G. T. Goodman, A. V. Capuco, and H. A. Tucker. 1981b. Prolactin regulation of cytological differentiation of mammary epithelial cells in periparturient cows. Endocrinology 109:31-40.

Auchtung, T. L., P. E. Kendall, J. L. Salak-Johnson, T. B. McFadden, and G. E. Dahl. 2003a. Effects of photoperiod and bromocriptine on prolactin receptor $\mathrm{mRNA}$ expression in bovine liver, mammary gland, and peripheral blood lymphocytes. J. Endocrinol. 179:347-356.

Auchtung, T. L., D. E. Morin, C. C. Mallard, and G. E. Dahl. 2003b. Photoperiod manipulation during the dry period: effects on general health and mastitis occurrence. Pages 278-279 in Proc. 42nd 
Annu. Natl. Mast. Mtg., Fort Worth, TX. Natl. Mastitis Counc., Madison, WI.

Auchtung, T. L., J. L. Salak-Johnson, D. E. Morin, C. C. Mallard, and G. E. Dahl. 2004. Effects of photoperiod on general health and cellular immune function during the dry period of dairy cows. J. Dairy Sci.

Berlanga, J. J., J. P. Garcia-Ruiz, M. Perrot-Applanat, P. A. Kelly, and M. Edery. 1997. The short form of the prolactin(PRL) receptor silences PRL induction of the $\beta$-casein gene promoter. Mol. Endocrinol. 11:1449-1457.

Binart, N., P. Imbert-Bollore, N. Baran, C. Viglietta, and P. A. Kelly. 2003. A short form of the prolactin (PRL) receptor is able to rescue mammopoiesis in heterozygous PRL receptor mice. Mol. Endocrinol. 17:1066-1074.

Dahl, G. E., B. A. Buchanan, and H. A. Tucker. 2000. Photoperiodic effects on dairy cattle: A review. J. Dairy Sci. 83:885-893.

Dahl, G. E., T. H. Elsasser, A. V. Capuco, R. A. Erdman, and R. R. Peters. 1997. Effects of a long daily photoperiod on milk yield and circulating concentrations of insulin-like growth factor. J. Dairy Sci. 80:2784-2789.

Dahl, G. E., and D. Petitclerc. 2003. Management of photoperiod in the dairy herd for improved production and health. J. Anim. Sci. 81(Suppl. 3):11-17.

Di Carlo, R., C. Bole-Feysot, O. Gualillo, R. Meli, M. Nagano, and P. A. Kelly. 1995. Regulation of prolactin receptor mRNA expression in peripheral lymphocytes in rats in response to changes in serum concentrations of prolactin. Endocrinology 136:4713-4716.

Djiane, J., L. M. Houdebine, P. A. Kelly, B. Teyssot, and I. Dusanter. 1983. Down-regulation of prolactin receptors and biological effects of prolactin in the mammary gland. Evidence for the existence of a prolactin second messenger. Pages 29-42 in Prolactin and Prolactinomas. G. Tolis, C. Stefanis, T. Mountokalakis, and F. Labric, ed. Raven Press, New York, NY.

Farr, V. C., K. Stelwagen, L. R. Cate, A. J. Molenaar, T. B. McFadden, and S. R. Davis. 1996. An improved method for routine biopsy of bovine mammary tissue. J. Dairy Sci. 79:543-549.

Feng, J. C., T. T. Loh, and H. P. Sheng. 1998. Lactation increases prolactin receptor expression in spleen and thymus of rats. Life Sci. 63:111-119.
Jabbour, H. N., and P. A. Kelly. 1997. Prolactin receptor subtypes: A possible mode of tissue specific regulation of prolactin function. Rev. Reprod. 2:14-18.

Jahn, G. A., M. Edery, L. Belair, P. A. Kelly, and J. Djiane. 1991 Prolactin receptor gene expression in rat mammary gland and liver during pregnancy and lactation. Endocrinology 128:29762984.

Kazmer, G. W., M. A. Barnes, R. M. Akers, and W. D. Whittier. 1986. Lactogenic hormone receptors in mammary membrane preparations from prepartum and 60 and 180 day postpartum Holstein cattle. J. Endocrinol. 109:175-180.

Miller, A. R. E., R. A. Erdman, L. W. Douglass, and G. E. Dahl. 2000. Effects of photoperiodic manipulation during the dry period of dairy cows. J. Dairy Sci. 83:962-967.

Miller, A. R. E., E. P. Stanisiewski, R. A. Erdman, L. W. Douglass, and G. E. Dahl. 1999. Effects of long daily photoperiod and bovine somatotropin (Trobest) on milk yield in cows. J. Dairy Sci. 82:1716-1722

Newbold, J. A., L. T. Chapin, S. A. Zinn, and H. A. Tucker. 1991. Effects of photoperiod on mammary development and concentration of hormones in serum of pregnant dairy heifers. J. Dairy Sci. 74:100-108.

Ormandy, C. J., M. Naylor, J. Harris, F. Robertson, N. D. Horseman, G. J. Lindeman, J. Visvader, and P. A. Kelly. 2003. Investigation of the transcriptional changes underlying functional defects in the mammary glands of prolactin receptor knockout mice. Recent Prog. Horm. Res. 58:297-323.

Schuler, L. A., R. J. Nagel, J. Gao, N. D. Horseman, and M. A Kessler. 1997. Prolactin receptor heterogeneity in bovine fetal and maternal tissues. Endocrinology 138:3187-3194.

Smith, J. J., A. V. Capuco, I. H. Mather, and B. K. Vonderhaar. 1993. Ruminants express a prolactin receptor of $\mathrm{Mr} 33,000-36,000$ in the mammary gland throughout pregnancy and lactation. J. Endocrinol. 139:37-49.

Touraine, P., M. C. Leite de Moraes, M. Dardenne, and P. A. Kelly. 1994. Expression of short and long forms of prolactin receptor in murine lymphoid tissues. Mol. Cell. Endocrinol. 104:183-190. 